\title{
Evaluation of the Causes of Perianal Abscess in Childhood
}

\section{çocuklarda Perianal Apse Nedenlerinin Değerlendirilmesi}

\author{
Deniz Aygün' ${ }^{1}$ Necla Akçakaya' ${ }^{1}$, Haluk Çokuğraş ${ }^{1}$, Yıldız Camcıoğlu' ${ }^{1}$ \\ ' Department of Pediatric Infection, Istanbul University Cerrahpasa School of Medicine, Istanbul, Turkey
}

Cite this article as: Aygün D, Akçakaya N, Çokuğraş H, Camcıoğlu Y. Evaluation of the causes of perianal abscess in childhood. J Pediatr Inf 2019;13(1):e21-e27

\begin{abstract}
Objective: Perianal abscesses are common disorders of childhood. Predisposing conditions like immunodeficiency syndrome and inflammatory bowel disease should be investigated especially in older children. In infants younger than six months of age, the presence of a congenital anomaly such as perianal fistula should be ruled out. In the present study, it was aimed to evaluate the clinical and laboratory findings of perianal abscesses in childhood.
\end{abstract}

Material and Methods: The medical records of patients hospitalized with the diagnosis of perianal abscesses in the pediatric infection disease department between December 2009 and December 2017 were evaluated retrospectively.

Results: There were 35 patients diagnosed with perianal abscesses, of whom 30 (85.7\%) were males and five (14.3\%) were females. Age distributions ranged from 2 to 156 months and mean patient age was 25.88 \pm 34.37 months. Eighteen (51.4\%) patients were younger than one year of age. Twenty-two (62.9\%) patients did not have any predisposing conditions. Five (14.3\%) patients had perianal fistula, 4 (11.4\%) patients had immunodeficiency, 3 (8.6\%) patients had inflammatory bowel disease and $1(2.9 \%)$ patient had hemangioma. Surgical drainage was performed in 9 (54.3\%) patients, 12 (34.3\%) patients did not have any invasive procedures, and 4 (11.4\%) patients developed spontaneous drainage. Fourteen (40\%) patients had a history of recurrence. The patients were divided into two groups according to recurrence. Male gender, older age, fever at admission, prolonged hospitalization, lymphocytosis and increased serum immunoglobulin levels were significantly associated with the recurrence of the perianal abscess.

Conclusion: Although, perianal abscesses are common in children, data in the management and treatment of the disease are limited. Children with recurrent perianal abscess should be examined in detail and risk factors be identified.

Keywords: Child, perianal abscess, perianal fistula
Öz

Giriş: Perianal apse, çocukluk çağında yaygın olarak görülen bir hastalıktır, özellikle büyük çocuklarda saptandığında altta yatan immünyetmezlik, inflamatuvar bağırsak hastalığı gibi predispozan faktörleri araştırmak gerekmektedir. Altı ayın altındaki süt çocuklarında ise hazırlayıcı nedenlerle nadiren ilişkili olup anal fistül gibi konjenital bir anomali varlığı dışlanmalıdır. Çalışmamızda çocukluk yaş grubunda perianal apse tanısı alan olguların klinik ve laboratuvar bulgularının değerlendirilmesi amaçlanmıştır.

Gereç ve Yöntemler: Aralık 2009-Aralık 2017 tarihleri arasında fakültemiz Çocuk Enfeksiyon Servisi'nde perianal apse tanısıyla yatırılan hastaların tıbbi kayıtları, geriye dönük olarak araştırmanın amaçları doğrultusunda incelendi.

Bulgular: Perianal apse tanısı alan 35 hastanın 30 (\%85.7)'u erkek, 5 (\%14.3)'i kızdı. Yaş ortalamaları $25.88 \pm 34.37$ aydı (2-156). Hastaların 18 (\%51.4)'i bir yaşından küçüktü. Hazırlayıcı nedenler araştırıldığında 22 (\%62.9) hastada herhangi hazırlayıcı bir patoloji saptanmadı. Beş (\%14.3) hastada perianal fistül, 4 (\%11.4) hastada immünyetmezlik, $3(\% 8.6)$ hastada inflamatuvar bağırsak hastalığı vardı, 1 (\%2.9) hastada hemanjiom zemininde apse gelişsmişti. On dokuz (\%54.3) hastaya cerrahi drenaj uygulandı, 12 (\%34.3) hastaya herhangi bir girişim uygulanmadı, 4 (\%11.4) hastada apse kendiliğinden drene oldu. On dört (\%40) hastada tekrarlayan perianal apse öyküsü vardı. Hastalar apse tekrarına göre iki gruba ayrılıp risk faktörleri karşılaştırıldı. Erkek cinsiyet, yaşın büyük olması, başvuru sırasında ateş varlığı, yatış süresinin uzun olması, lenfositoz, serum immünglobülin düzeyinde yükseklik ile perianal apsenin tekrarlaması arasında istatistiksel anlamlı ilişki saptandı.

Sonuç: Perianal apseler çocuklarda sık görülmekle birlikte hastalığın yönetiminde ve tedavisindeki veriler kısıtlıdır. Tekrarlayan perianal apse şikayeti olan çocuklar ayrıntılı olarak tetkik edilmeli ve risk faktörleri belirlenmelidir.

Anahtar Kelimeler: Çocuk, perianal fistül, perianal apse

Yazışma Adresi / Correspondence Address

\section{Deniz Aygün}

İstanbul Üniversitesi Cerrahpaşa Tıp Fakültesi,

Çocuk Enfeksiyon Bilim Dalı, İstanbul-Türkiye

E-mail: fdenizaygun@gmail.com 


\section{Introduction}

Perianal abscess is an anorectal disease seen vey commonly not only in adulthood but also in childhood. Patients generally refer to hospitals with complaints such as swelling in the anal region, tenderness and fever. Perianal abscesses forming as a result of obstruction of the anal crypts and glands are frequently seen in male children under the age of 1 (1-4). It has been suggested that androgen excess or the imbalance between androgen and estrogen causes the formation of perianal abscess $(5,6)$. In 30-50\% of perianal abscesses, fistula can develop between the perianal skin and anal canal due to the surfacing of the inflammation. Immunodeficiency or inflammatory bowel diseases (IBD) in older children and a congenital anomaly like anal fistula in children under the age of 1 can be predisposing conditions to the formation of perianal abscess $(6,7)$. Along with the preference of conservative treatment methods in perianal abscess treatment, surgical intervention may be necessary in symptomatic patients (8). Data on the management of perianal abscess in childhood are limited and are based mostly on surgical reports and clinical experience. To that end, this study aimed to report the predisposing conditions, treatment preferences, outcomes and clinical and laboratory findings of the patients hospitalized in our clinic for perianal abscess.

\section{Materials and Methods}

\section{Study Plan}

Data of all patients hospitalized with the diagnosis of perianal abscess between December 2009 and December 2017 in the Pediatric Infection Disease Department of Istanbul University Cerrahpasa Medical Faculty were retrospectively reviewed from patient files and electronic record system. Consent from all parents of our patients and approval from the local ethics committee of our faculty (21.05.2018-29430533) were received for the study.

\section{Patient Selection and Data Collection}

The patients were evaluated for age, gender, complaints at admission and treatment method. Hemogram, C-reactive protein (CRP), erythrocyte sedimentation rate (ESR), serum immunoglobulin (Ig) levels, lymphocyte sub-groups, and nitroblue tetrazolium test (NBT) were assessed in all patients. Abscess culture from patients receiving spontaneous or surgical drainage and blood culture from all patients that had fever were taken. Antibiotherapy preferences and length of hospital stay according to culture antibiogram results were recorded. Prolonged diarrhea and presence of recurrent abscess were investigated.

\section{Statistical Analysis}

SPSS (21.0 version, IBM Company, SPSS Inc.) was used for statistical analysis. Numerical values were stated by mean \pm standard deviation and categorical data by frequency $(n)$ and percentage (\%). Statistical significance between the groups was analyzed by one way ANOVA. Pearson chi-square test was used for the evaluation of the association between two nominal variables. The association between recurrent perianal abscess and laboratory findings were assessed by ROC curve analysis. P value below 0.05 was accepted statistically significant.

\section{Results}

\section{Demographics}

A total of 35 patients, of whom $30(85.7 \% 0$ were males and 5 (14.3\%) were females, were hospitalized and treated for perianal abscess. Mean age of the patients was $25.88 \pm 34.37$ months (2156). Eighteen of the patients (51.4\%) were under the age of 1. Fever was detected in 12 (34.2\%) patients at admission. Recurrent perianal abscess and prolonged diarrhea were found in 14 (40\%) and 7 (20\%) patients, respectively.

\section{Clinical and Laboratory Factors Associated with Perianal Abscess}

Laboratory evaluation of the patients was as follows; mean sedimentation: $4457 \pm 24.40 \mathrm{~mm} / \mathrm{h}$, mean CRP: $8.09 \pm 6.60 \mathrm{mg} /$ $\mathrm{dL}$, mean leukocyte count: $15.412 \pm 6729 / \mathrm{mm}^{3}$, mean neutrophil count: $10.416 \pm 7135 / \mathrm{mm}^{3}$, mean lymphocyte count: 3733 $\pm 1757 / \mathrm{mm}^{3}$, mean thrombocyte count: $360.108 \pm 154.391 /$ $\mathrm{mm}^{3}$, and mean hemoglobin: $11.1 \pm 1.6 \mathrm{~g} / \mathrm{dL}$. When predisposing conditions were scrutinized, no predisposing pathology was determined in 22 (62.9\%) patients. Five (14.3\%) patients had perianal fistula, 4 (11.4\%) patients had immunodeficiency, $3(8.6 \%)$ patients had inflammatory bowel disease and $1(2.9 \%)$ patient had hemangioma. Immune system evaluation was carried out in all patients. Two of our patients had already been followed by the Pediatric Immunology Polyclinic of our hospital for chronic granulomatosis disease (CGD) and Wiskott Aldrich syndrome. Two patients were diagnosed with CGD during hospitalization. Two of the patients were priorly diagnosed with IBD, and infantile IBD was suspected in an 18-months-old patient.

Surgical drainage was performed in $19(54.3 \%)$ patients. No invasive procedures were carried out in 12 (34.3\%) patients, and the abscesses were spontaneously drained in $4(11.4 \%)$. There was growth in the drainage cultures of 17 (48.6\%) patients. Klebsiella pneumoniae that produces wide-spectrum beta-lactamase (WSBL) was detected in 11 (31.4\%) patients, Escherichia coli that produces WSBL was confirmed in 5 (14.3\%) patients, and enterococcus-type microorganism was seen in $1(2.9 \%)$ patient. There was growth in the blood culture of $3(8.6 \%)$ patients. Stenotrophomonas maltophilia grew in one patient diagnosed with CGD and $K$. pneumoniae in two. Our patient with a preliminary diagnosis of IBD, in whose blood culture $K$. pneumoniae that produces WSBL grew, died due to sepsis. Having no other disease than liminal mental retardation and microcephaly, the 
Table 1. Patient demographics

\begin{tabular}{|c|c|}
\hline Total patient number & $\begin{array}{c}(n=35) \\
\text { Mean } \pm \text { SD }\end{array}$ \\
\hline $\begin{array}{l}\text { Gender } \\
\text { Male } \\
\text { Female }\end{array}$ & $\begin{array}{c}30(85.7 \%) \\
5(14.3 \%)\end{array}$ \\
\hline $\begin{array}{l}\text { Age distribution of the patients } \\
\text { (month) }\end{array}$ & $25.88 \pm 34.37(2-156)$ \\
\hline $\begin{array}{l}\text { Number of patients younger than } \\
1 \text { year of age }\end{array}$ & $18(51.4 \%)$ \\
\hline Presence of fever & $12(34.2 \%)$ \\
\hline History of recurrence & $14(40 \%)$ \\
\hline Prolonged diarrhea & $7(20 \%)$ \\
\hline Presence of fistula & $5(14.3 \%)$ \\
\hline Immunodeficiency & $4(11.4 \%)$ \\
\hline Inflammatory bowel disease & $3(8.6 \%)$ \\
\hline Surgical drainage & $19(54.3 \%)$ \\
\hline Growth in abscess culture & $17(48.6 \%)$ \\
\hline Growth in blood culture & $3(8.6 \%)$ \\
\hline Mean length of hospital stay (day) & $21.37 \pm 12.81$ \\
\hline
\end{tabular}

infection advanced to the lower abdomen, and femur and osteomyelitis developed in an 11-year-old patient with a diagnosis of perianal abscess secondary to anal fissure that developed after prolonged diarrhea. WSBL-producing $E$. coli developed in two drainage cultures of this case. Deeply located fistula was detected in the patient whose immune system evaluation was normal. Meropenem-amicasin, cephazolin-amicasin, and ampicillin-cephotaxime treatments were administered to 17 (48.6\%), $14(40.0 \%)$ and $4(11.4 \%)$ patients, respectively. Mean treatment and length of hospital stay of the patients were $21.37 \pm 12.81$ days. Table 1 shows the demographics of the patients.

\section{Clinical and Laboratory Factors Associated with Patients Having Recurrent Perianal Abscess}

The patients were divided into two groups as regards abscess recurrence, and the risk factors were compared. A statistically significant relation was found between male gender, older age, fever at admission, longer hospital stay, lymphocytosis, elevated levels of serum $\lg G, \lg M$, lgA, lgE and recurrence of the perianal abscess. Respectively, $p$ values were as follows: $p=0.049, p=0.024, p=0.006, p=0.013, p=0.025, p=0.001, p=$ $0.016, p=0.011, p=0.004$. History of prolonged diarrhea was lower in patients with recurrent abscess $(p=0.028)$ (Table 2$)$.

Table 2. Comparison of risk factors according to abscess recurrence

\begin{tabular}{|c|c|c|c|}
\hline & \multicolumn{2}{|c|}{ Recurrence } & \multirow[b]{2}{*}{$\mathbf{p}$} \\
\hline & Yes $(n=14)$ & No $(n=21)$ & \\
\hline $\begin{array}{l}\text { Gender } \\
\text { Male } \\
\text { Female }\end{array}$ & $\begin{array}{c}10(71.5 \%) \\
4(28.5 \%)\end{array}$ & $\begin{array}{c}1(4.8 \%) \\
20(95.2 \%)\end{array}$ & 0.049 \\
\hline Age (month) & $41.71 \pm 48.70$ & $15.33 \pm 13.23$ & 0.024 \\
\hline Fever & $38.42 \pm 0.76$ & $37.57 \pm 0.89$ & 0.006 \\
\hline Leucocyte count & $17807.14 \pm 8690.09$ & $13816.19 \pm 4606.00$ & 0.086 \\
\hline Neutrophil & $11980.71 \pm 10267.72$ & $9372.86 \pm 3895.49$ & 0.296 \\
\hline Lymphocyte & $4535.71 \pm 2268.38$ & $3198.57 \pm 1074.08$ & 0.025 \\
\hline $\mathrm{Hgb}$ & $11.09 \pm 1.08$ & $11.48 \pm 1.07$ & 0.302 \\
\hline Thrombocyte & $256729 \pm 249073$ & $248349 \pm 172840$ & 0.907 \\
\hline CRP & $8.97 \pm 7.32$ & $7.50 \pm 6.20$ & 0.527 \\
\hline Sedimentation & $49.36 \pm 24.05$ & $41.38 \pm 24.69$ & 0.351 \\
\hline $\lg G$ & $867.21 \pm 398.95$ & $536.43 \pm 148.07$ & 0.001 \\
\hline $\lg M$ & $98.41 \pm 91.69$ & $46.52 \pm 16.64$ & 0.016 \\
\hline $\lg A$ & $68.79 \pm 70.09$ & $24.79 \pm 14.23$ & 0.011 \\
\hline $\lg \mathrm{E}$ & $79.33 \pm 104.25$ & $9.92 \pm 8.86$ & 0.004 \\
\hline Length of hospital stay & $27.78 \pm 16.41$ & $17.10 \pm 7.49$ & 0.013 \\
\hline Culture taken & $10(71.5 \%)$ & $13(61.9 \%)$ & 0.193 \\
\hline Prolonged diarrhea & $1(7.1 \%)$ & $6(28.5 \%)$ & 0.028 \\
\hline Recurrences & $5(35.7 \%)$ & $9(42.8 \%)$ & 0.129 \\
\hline Groth in wound & $6(42.8 \%)$ & $11(52.3 \%)$ & 0.063 \\
\hline Surgical drainage & $8(57.1 \%)$ & $11(52.3 \%)$ & 0.411 \\
\hline
\end{tabular}


Table 3. Evaluation of the relation between recurrent perianal abscess and lg levels with ROC analysis

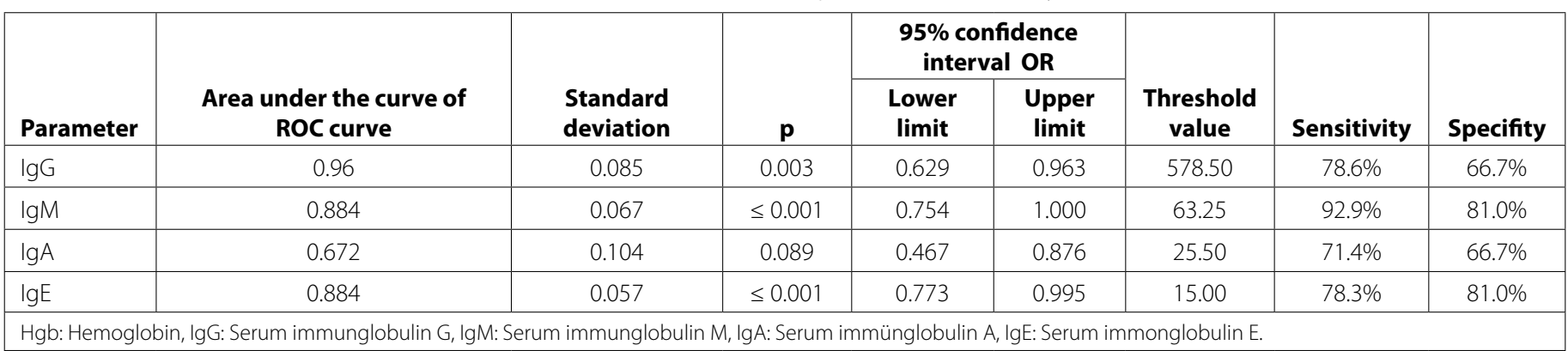

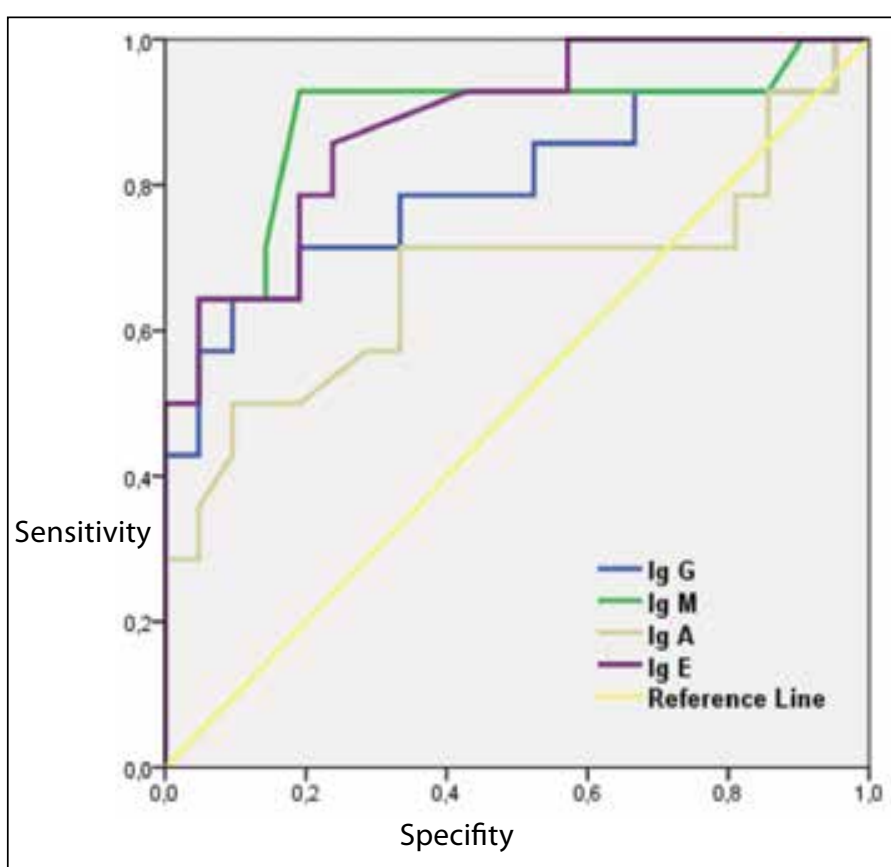

Figure 1. Relation between recurrent perianal abscess and immunoglobulin levels.

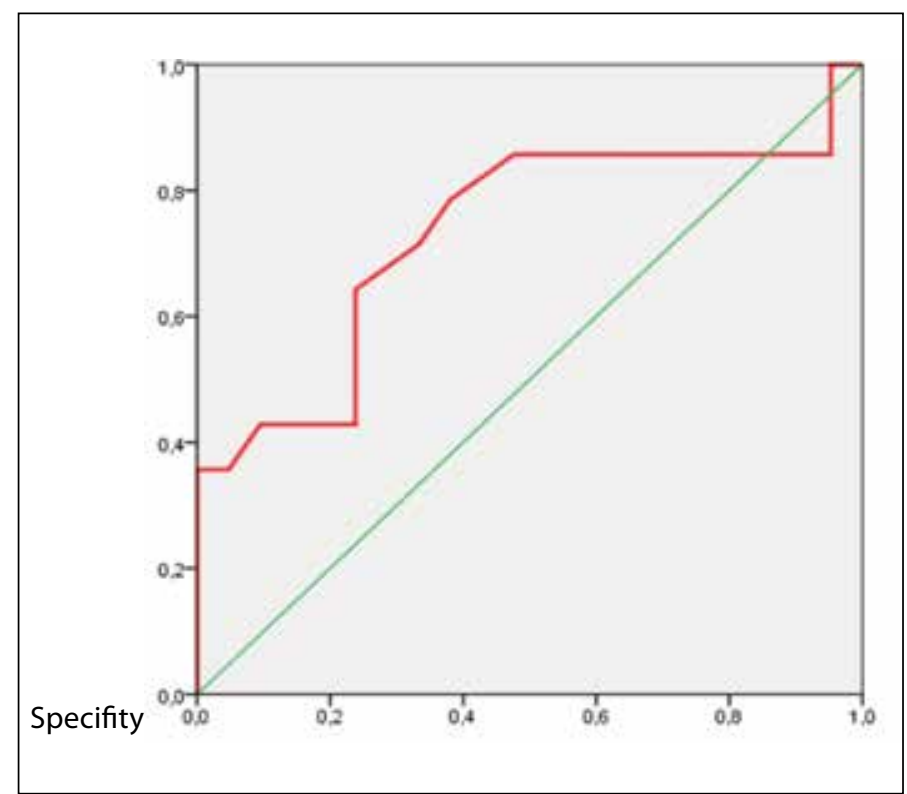

Figure 2. Relation between recurrent perianal abscess and hemogram parameters.

\section{ROC Analysis of the Relation Between Recurrent Perianal Abscess and Ig Levels}

For the relation between recurrent perianal abscess and Ig levels, ROC curve analysis was performed, and specifity and sensitivity were detected as $78.6 \%$ and $66.7 \%$ respectively for a cut-off point of $578.50 \mathrm{mg} / \mathrm{dL}$ and area under the curve (AUC) of 0.796 for lgG. On the same curve, specifity and sensitivity were $92.9 \%$ and $81.0 \%$ respectively for a cut-off point of $63.25 \mathrm{mg} / \mathrm{dL}$ and AUC of 0.884 for IgM. Specifity and sensitivity were $71.4 \%$ and $66.7 \%$ respectively for a cut-off point of $25.50 \mathrm{mg} / \mathrm{dL}$ and AUC of 0.672 for $\lg A$ and specifity and sensitivity were $78.3 \%$ and $81.0 \%$ respectively for a cut-off point of $15.00 \mathrm{mg} / \mathrm{dL}$ and AUC of 0.884 (Table 3). Relation between recurrent perianal abscess and IgG levels are shown in ROC curve Figure 1.

\section{ROC Analysis of the Relation Between Recurrent Perianal Abscess and Hemogram Parameters}

Recurrence was only found to be associated with lymphocyte count when ROC analysis was performed for the relation between recurrent perianal abscess and hemogram parameters (Figure 2). Specifity and sensitivity were detected as $78.6 \%$ and $61.9 \%$ respectively for a cut-off point of $3450 \mathrm{~mm}^{3}$ and area under the curve (AUC) of 0.731 for lymphocyte value (Table 4).

\section{Discussion}

Perianal abscess is mostly the disease of newborn and infancy periods, and it is seen at a frequency of $0.5-4.3 \%$ in infants. Rates of cases under the age of 1 have been reported as $57-86 \%$, and infancy frequency in perianal abscesses in our country has been put forth between $62 \%$ and $85.1 \%$ in studies conducted in our country $(1,2,4,5,9,10)$. In our study, only $51.4 \%$ of our cases was under the age of 1 and the mean age was 25.88 \pm 34.37 months.

As in other perianal region pathologies, male dominancy is present in perianal abscesses. While Meyer et al. have reported the rate of male gender as $92.5 \%$, male dominance in Serour et al's report has been determined as $97 \% .85 .7 \%$ of the cases in our study was male, which was lower than the other reports in the literature $(7,9)$. The reason for male dominance in perianal abscesses is not clearly known. The hypotheses put forward in- 
Table 4. Evaluation of the relation between recurrent perianal abscess and hemogram parameters with ROC analysis

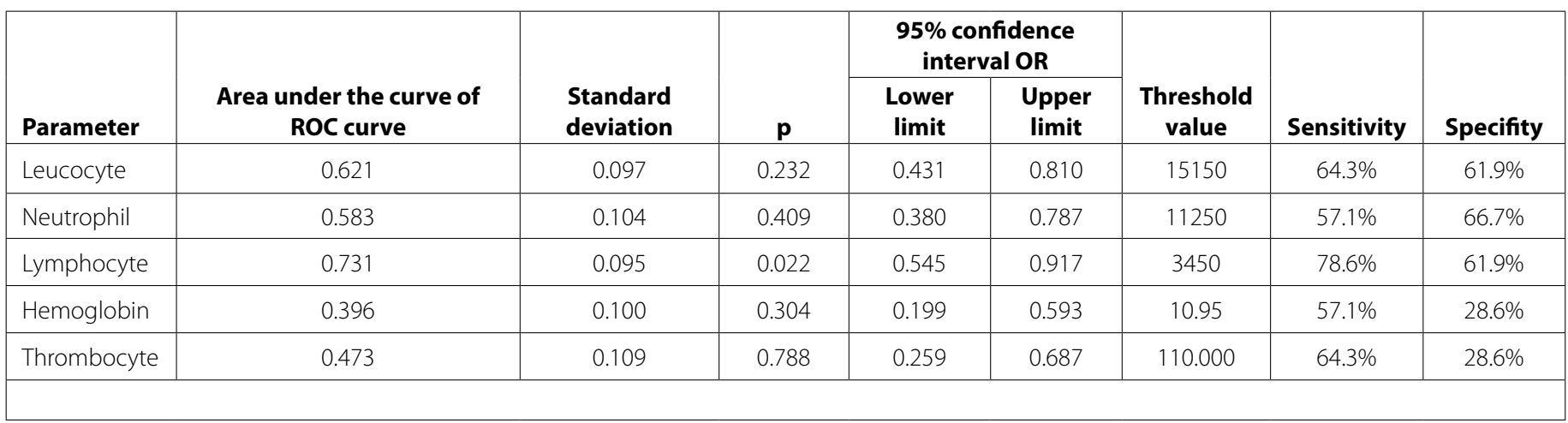

clude the fact that blood testosterone levels in male babies reach the maximum level between the $1^{\text {st }}-3^{\text {rd }}$ months of prepubertal period, deep and thick Morgagni crypts are infected with the androgen effect and that there is an imbalance between androgen and estrogen levels $(4,10,11)$.

Predisposing conditions should be investigated in patients detected having perianal abscess. Arditi et al. have indicated that there is a predisposing factor in $52 \%$ of 50 cases (12). It has been suggested that perianal abscesses in infants are associated with congenital anomalies like fistula. Shafer et al. have emphasized that perianal fistulas can be related to thickened dentate line in addition to deep and thick Morgagni crypts and pave the way for abscess formation (11). Apart from the reports stating rates of fistula frequency as high as $60 \%-88 \%$, there are reports indicating rates as low as $15-20 \%$ $(5,9,12-14)$. Fistula frequency was reported as $14.3 \%$ in our study. Skin infections and setback in the cell migration from the urogenital sinus during embryologic development of the perineum are other possibilities considered (3). Skin infection hypothesis is supported by the gluteal-localized abscess development in hemangioma. No pathology was detected in 22 of our patients (62.9\%).

All patients with recurrent perianal abscess complaint should be evaluated for immunodeficiency, and CGD should be ruled out. Perianal abscess formation has been reported in $15 \%-18 \%$ of the patients diagnosed with chronic granulomatosis disease (15). As perianal abscess can be the first finding of these patients at admission, it can also develop later in life. Two of our patients had referred to us with perianal abscess complaint and received CGD diagnosis. The case with CGD had developed perianal abscess for the first time at the age of 12 . Immunodeficiency rate in our study was detected as $11.4 \%$. Due to the fact that immunodeficiency scans are expensive and carried out in a limited of centers, it is not routinely recommended in patients having perianal abscesses. However, since our university is the reference center for immunodeficiency, it was investigated in all patients.
Perianal abscess can be a complication or even the first finding of IBD, and especially Crohn's disease. Chronic immunosuppression, diarrhea, and delayed wound healing can be considered the causes of perianal abscess in these patients. Perianal abscesses are more frequently complicated in patients diagnosed with inflammatory bowel disease (16). In a wide-scale, retrospective study including 7218 cases with perianal disease, complication rate in patients with Crohn's disease has been found as 24 and as $4.8 \%$ in patients without any predisposing conditions $(16,17)$. Two of our cases had previously received Crohn's disease diagnosis. An 18-month-old female case with history of recurrent perianal abscess accompanied with perianal fistula and who was suspected of having IBD was lost due to sepsis while being treated in the department. K. pneumonia had grown in the abscess and blood culture of the case.

Generally, gastrointestinal flora pathogens grow in perianal abscess culture materials. Along with the fact that $E$. coli is the most frequently detected pathogen, Klebsiella spp, Bacteriodes fragilis ve Staphylococcus aureus are other microorganisms. Brook et al. have determined aerobe and anaerobe flora pathogens in 104 cases, anaerobe bacteria in 27 cases, and aerobe or facultative bacteria in 13 cases in their culture examination including 144 cases (18). There was growth in the drainage cultures of 17 (48.6\%) of our cases, and the most commonly detected microorganism was WSBL-producing K. pneumoniae. Along with the fact that differences in the growing pathogen as regards gender has been suggested in two different reports and that $E$. coli has been more frequently seen in males and $S$. aureus in females, a difference was not detected in our study in terms of growth as regards gender (19). According to culture antibiogram results, concomitant use of meropenem and amicasin was preferred in $48.6 \%$ of the cases.

Although there is no consensus reached on the treatment approach to perianal abscesses in the literature, medical follow-up is more commonly preferred. Many authors recommend a conservative treatment consisting of a hip bath and 
antiseptic and antibiotic use $(8,9,20)$. Even though Kubota et al. have reported success in local abscess treatment with fibroblast growth factor (FGF) which is a cytokine effective in angiogenesis and tissue regeneration, it is not yet a supported treatment choice (21). A group of authors indicates that the perianal abscess must certainly be drained and that medical treatment results in longer hospital stay and antibiotic use $(22,23)$. On the other hand, it has been reported that surgical intervention increases the risk of perianal fistula formation and recurrence (8). Surgical drainage had to be performed in 19 (54.3\%) patients in our study; however, a statistically significant relation was not detected between surgical intervention and abscess recurrence.

When risk factors for perianal abscess recurrence were investigated, a statistically significant relation was found between the recurrence of perianal abscess and the male gender, older age, fever at admission, longer hospital stay, lymphocytosis, and elevated serum immunoglobulin level. We are of the opinion that more frequent encountering of perianal abscess in males and high levels of immunodeficiency and IBD in patients with predisposing factors explain the risk factors for abscess recurrence.

As seen in ROC curve, IG levels were detected distinctly higher in patients with recurrent perianal abscesses. Area under the curve for IgM and IgE was determined markedly high (AUC: 0.884). High serum Ig levels can be explained by the increase in inflammation, as in the high lg levels in our CGD diagnosed cases.

Among the hemogram parameters, which are other risk factors for patients with perianal abscess, lymphocyte level was detected statistically significant on the ROC curve. AUC for ROC curve was 0.731 for lymphocyte value at admission.

There are some limitations to our study. First, our study was constructed as a retrospective one with a few number of patients. Second, perianal abscess localizations were not recorded and a standard surgical method was not specified. On the other hand, wide disease profile, high growth rate in tissue and blood cultures and significant risk factors of perianal abscess recurrence, and especially elevated serum Ig and lymphocyte values make our study valuable.

All in all, along with the fact that perianal abscesses are frequently seen in children, data are limited in the management and treatment of the disease. Children with recurrent perianal abscess complaint should be examined thoroughly and risk factors be identified.

Ethics Committe Approval: Consent from all parents of our patients and approval from the local ethics committee of our faculty (21.05.2018-29430533) were received for the study.

Peer-review: Externally peer-reviewed.
Author Contributions: Concept - YC, DA, HC, NA; Design - DA, YC, HC, NA; Supervision - YC, HC; Materials - DA, YC, HC, NA; Data Collection - DA, YC, HC, NA; Analysis - DA, YC, HC; Literature Review - DA, YC; Writing - DA, YC; Critical Review - YC, HC, NA.

Conflict of Interest: No conflict of interest was declared by the authors.

Financial Disclosure: The authors declared that this study has received no financial support.

\section{References}

1. Tanır Basaranoglu S, Ozsurekci Y, Cengiz AB, Karadag Oncel E, Aykac $K$, Kara $A$, et al. Perianal abscess in children: A pediatric infectious disease perspective. An Pediatr (Barc) 2018 Jun 4. pii: S16954033(18)30177-2.

2. Ezer SS, Oğuzkurt $P$, Ince E, Hiçsönmez A. Perianal abscess and fistula-in-ano in children: aetiology, management and outcome. J Paediatr Child Health 2010;46:92-5.

3. Al-Salem AH, Laing W, Talwalker V. Fistula-in-ano in infancy and childhood. J Pediatr Surg 1994;29:436-8.

4. Festen C, van Harten H. Perianal abscess and fistula-in-ano in infants. J Pediatr Surg 1998;33:711-3.

5. Afşarlar CE, Karaman A, Tanır G, Karaman I, Yılmaz E, Erdoğan D, et al. Perianal abscess and fistula-in-ano in children: clinical characteristic, management and outcome. Pediatr Surg Int 2011;27:1063-8.

6. Fitzgerald RJ, Harding B, Ryan W. Fistula-in-ano in childhood: a congenital etiology. J Pediatr Surg 1985;20:80-1.

7. Meyer $T$, Weininger $M$, Höcht B. Perianal abscess and anal fistula in infancy and childhood. A congenital etiology? Chirurg 2006;77:1027-32.

8. Christison-Lagay ER, Hall JF, Wales PW, Bailey K, Terluk A, Goldstein $A M$, et al. Nonoperative management of perianal abscess in infants is associated with decreased risk for fistula formation. Pediatrics 2007; 120:548-52.

9. Serour F, Somekh E, Gorenstein A. Perianal abscess and fistula-in-ano in infants: a different entity? Dis Colon Rectum 2005;48:359-64.

10. Poenaru D, Yazbeck SV. Anal fistula in infants: etiology, features, management. J Pediatr Surg 1993;28:1194-5.

11. Shafer $A D, M c G l o n e ~ T P$, Flanagan RA. Abnormal crypts of Morgagni: the cause of perianal abscess and fistula-in-ano. J Pediatr Surg 1987;22:203-4.

12. Arditi $M$, Yogev R. Perirectal abscess in infants and children: Report of 52 cases and review of the literature. Pediatr Infect Dis J 1990;9:411-5.

13. Murthi GV, Okoye BO, Spicer RD, Cusick EL, Noblett HR. Perianal abscess in childhood. Pediatr Surg Int 2002;18:689-91.

14. Christison-Lagay ER, Hall JF, Wales PW, Bailey K, Terluk A, Goldstein $A M$, et al. Nonoperative management of perianal abscess in infants is associated with decreased risk for fistula formation. Pediatrics 2007;120:548-52.

15. Winkelstein JA, Marino MC, Johnston RB Jr, Boyle J, Curnutte J, Gallin Jl, et al. Chronic granulomatous disease. Report on a national registry of 368 patients. Medicine (Baltimore) 2000;79:155-69.

16. Zwintscher NP, Shah PM, Argawal A, Chesley PM, Johnson EK, Newton $C R$, et al. The impact of perianal disease in young patients with inflammatory bowel disease. Int J Colorectal Dis 2015;30:1275-9.

17. Causey MW, Nelson D, Johnson EK, Maykel J, Davis B, Rivadeneira DE, et al. An NSQIP evaluation of practice patterns and outcomes following surgery for anorectal abscessand fistula in patients with and without Crohn's disease. Gastroenterol Rep (Oxf) 2013;1:58-63. 
18. Brook I, Frazier EH. The aerobic and anaerobic bacteriology of perirectal abscesses. J Clin Microbiol 1997;35:2974-6.

19. Wright WF. Infectious diseases perspective of anorectal abscess and fistula-in-ano disease. Am J Med Sci 2016;351:427-34.

20. Rosen NG, Gibbs DL, Soffer SZ, Hong A, Sher M, Pe na AJ. The nonoperative management of fistula-in-ano. J Pediatr Surg 2000;35: 938-9.

21. Kubota $M$, Hirayama $Y$, Okuyama $N$. Usefulness of bFGF spray in the treatment of perianal abscess and fistula-in-ano. Pediatr Surg Int 2010;26:1037-40.
22. Oh JT, Han A, Han SJ, Choi SH, Hwang EH. Fistula-in-ano in infants: Is nonoperative management eff ective? J Pediatr Surg 2001;36:1367-9.

23. Niyogi A, Agarwal T, Broadhurst J, Abel RM. Management of perianal abscess and fistula-in-ano in children. Eur J Pediatr Surg 2010; 20:35-9. 